HAVRAN Zsolt

\title{
A JÁTÉKOSVÁSÁRLÁS ÉS AZ EREDMÉNYESSÉG KAPCSOLATA A HIVATÁSOS LABDARÚGÁSBAN
}

A hivatásos labdarúgó-csapatokat múködtető vállalatok gyakran helyezik sportszakmai céljaikat a pénzügyi céljaik elé, költségvetésük jelentős részét költik játékosok szerződtetésére, fizetésére, hogy sportszakmai értelemben növeljék versenyképességüket. A dolgozat a nemzetközi szakirodalom összefoglalásával arra keresi a választ, hogy a sportvállalatok sportszakmai és pénzügyi eredményességére milyen hatással vannak a humán erőforrás fejlesztésére költött források. A vizsgált, nagy európai bajnokságokban (angol, német, olasz, spanyol) igazolták a pozitív kapcsolatot a klubok személyi jellegú kiadásai, a játékosok egyéni teljesítménye és a csapatteljesítmény között, valamint a csapat teljesítményének javulása esetében az árbevétel emelkedését is kimutatták. A játékosokra költött kiadások növelése (beleértve a vásárlást és a bérek kifizetését, de nem bevonva az utánpótlás-nevelést) tehát az árbevétel növekedésével jár, azonban a nyereség növekedését már nem eredményezik, mert a bérek további, jelentős növekedése ezt akadályozza. A sportvállalatoknak meg kell határozniuk fó stratégiai céljukat és meg kell vizsgálniuk azt a kérdést, hogy milyen sportszakmai célokat szabad kitúzniük a szúkös gazdasági lehetôségeikhez képest. A humán erôforrással való tudatos és tervezett gazdálkodás jelentheti hosszú távon a fennmaradást és a sportszakmai, pénzügyi stratégiai célok teljesíthetóségét.

\section{Kulcsszavak: hivatásos labdarúgás, sportvállalat, játékospiac, humánerőforrás-menedzsment}

Az üzleti vállalkozások eredményességét nagyban befolyásolja a rendelkezésre álló tudás minősége, felhasználásának hatékonysága. Kiemelten igaz ez az úgynevezett tudásintenzív iparágakban, és szúkebb értelemben ide tartoznak a hivatásos sportcsapatokat múködtetô sportvállalatok is (Stocker, 2013, p. 25.). A hivatásos sportoló igen speciális képességekkel rendelkező munkaeró, nehezen helyettesíthetô, főleg a kiemelkedő képességú játékosok jelentenek szúk erôforrást (András, 2004). A hivatásos sport egyik sajátossága, hogy elválhatnak a sportszakmai és a pénzügyi célok, eredmények, gyakran alárendeltek a pénzügyi célok a sportszakmai céloknak. Másik kiemelt tulajdonsága a hivatásos sportnak a speciális munkaeró-piaci múködés, amely szerint egy hivatásos játékos határozott időre átengedi játékjogának használati jogát a sportvállalat, a klubja számára. Cserébe a játékos aláírási pénzre tarthat igényt, érvényes szerződés esetén pedig ki kell ôt vásárolnia a szerződésből az új klubjának (átigazolás) (András, 2004). A labdarúgó-klubokat, a csapatokat múködtető sportvállalatokat az elmúlt évtized tendenciái alapján sokkal inkább a sportbeli sikerek érdekelték, mint a pénzügyi eredmények, amelynek következménye, hogy az európai klubokat folyamatosan növekvő adósságok jellemzik (András - Havran, 2015). A kiadások legnagyobb részét a játékosok igazolása és fizetése teszi ki, ami rávilágít a nemzetközi labdarúgás üzleti múködésének legfontosabb pontjaira. Ezeket számos nemzetközi kutatásban is bizonyították, amelyek eredményeit hivatott az alábbi tanulmány összefoglalni.

Európában a csapatsportok közül a labdarúgás múködése tekinthetô a leginkább üzletinek, a legtöbb elérhetô adattal és empirikus kutatással is ez a sportág rendelkezik, ezért lehet alkalmas példa a hivatásos labdarúgás a humán erőforrásba történő befektetés hatásainak sportbeli bemutatására. A humán erőforrásba történő beruházás a sportvállalatok esetében jelentheti új játékosok vásárlását és a saját utánpótlás kinevelését is. Tanulmányom célja a hivatásos játékosok játékjogával történő kereskedelem nehézségeinek és specialitásainak bemutatása, a nemzetközi szakirodalom alapján a játékosokra költött pénzügyi eszközök hatásainak rendszerezése, nem érintve az utánpótlás-nevelést. 
E tanulmány összefoglalja és rendszerezi az elmúlt két évtizedben született, releváns nemzetközi tanulmányokat, azok eredményeit. A tanulmány segítséget jelenthet további empirikus vizsgálatok elvégzéséhez, szabályozási kérdések megvitatásához, valamint sportvállalatok stratégiájának megalapozásához.

A tanulmányban ismertetem a hivatásos labdarúgás üzleti múködésének megértését segító releváns sportszakmai és üzleti definíciókat, illetve azok összefüggéseit. A dolgozat tehát nem vizsgálja a nem hivatásos sportokat, az egyéni sportokat, vagy más csapatsportokat, illetve a női labdarúgást sem. Ennek oka egyrészt, hogy a férfi hivatásos labdarúgás rendelkezik a legtöbb üzleti elemmel Európában (így ennek elemzése jelenthet komoly tanulságokat más, fejlődő sportágaknak), másrészt ezen a területen érhető el a legtöbb tanulmány, elemzés, adat. A nagy észak-amerikai bajnokságok (kosárlabda, jégkorong, amerikai futball és baseball) üzleti múködésében egyértelmúen azonosítható a sportvállalatok pénzügyi és sportszakmai célja, a sportvállalatok valóban profitot realizálnak, a tulajdonosok főleg üzleti szempontok alapján döntenek a befektetésekről (Dietl et al., 2011). Az amerikai bajnokságok bemutatása a dolgozatnak nem célja, egyrészt azért, mert önmagában is külön tanulmány megírását indokolná, másrészt az európai labdarúgás problémakörét szeretném bemutatni, amely struktúrájában, versenykiírásában, játékospiaci szabályozásában és hagyományaiban sem összehasonlítható az amerikai modellel.

\section{A hivatásos labdarúgás üzleti múködése és a játékospiac legfőbb sajátosságai}

Szabados (2003) az alapján tipizálta a hivatásos labdarúgóklubok stratégiáját, hogy létezik-e egyértelmúen fölérendelt cél, és ha igen, akkor a sportszakmai vagy a pénzügyi cél jelenik-e meg e tekintetben. A sportszakmai célokért legfőképp a hivatásos játékosok tehetnek, ezért is jelentik ők a legfontosabb erőforrást, és ezért is költenek erőn felül erre a területre a klubok. Ennek jó példáját mutatja az Európai Labdarúgó Szövetség (UEFA) jelentése, amely szerint az UEFA által szervezett kupákban induló klubok a bevételeik több mint 60\%-át fizetésekre, prémiumokra és hozzájuk kapcsolódó adókra költik. Ráadásul, a személyi jellegú ráfordítások $79 \%$-át játékosokra költik, mindössze $21 \%$-a megy a technikai és adminisztratív személyzet költségeire (UEFA, 2013, p. 44.).

A hivatásos sportban is azonosíthatók a vállalat-gazdaságtanban ismert értékek (Chikán, 2008), amelyek olyan termékek vagy szolgáltatások, amelyek fogyasztói vagy ügyféligényt elégítenek ki, ezért hajlandók értük fizetni. András (2003) alapján a hivatásos labdarúgás egyik fontos értékteremtői a klubok, akik közvetlenül (létesítményhez kapcsolódó jogosultságok, indulási jog, licenc, játékos vagyoni jog, márkaérték-goodwill), valamint közvetett formában (a médián, jellemzően a televízión keresztül) is részt vesznek az értékteremtésben. A klubok értékteremtó tényezője lehet a játékosállománya, sztárjainak köre, futballjának stílusa, arculatának milyensége (András, 2003, p. 41.). A hivatásos labdarúgásban több ilyen érték azonosítható, de elmondható, hogy „a labdarúgók az alapszolgáltatás minőségének letéteményesei" (András, 2003, p. 40.).

A hivatásos labdarúgók adásvételének helye a játékospiac, a csere tárgya pedig a labdarúgó-játékjog használatának átruházása. A játékosvásárlás a futballtársaság szempontjából kettős ügyletnek tekinthető: egyszerre jelent munkaeró-felvételt, valamint a vagyoni jog megvásárlásával egy olyan befektetést, mely többféle módon (kölcsönbeadás, eladás, marketingcélok) is hasznosítható (András, 2003). Carmichael (2006) szerint a játékospiac nem lehet tökéletesen versenyző piac, mert egyrészt nincs tökéletes informáltság (bizonytalan a játékos minősége, elkötelezettsége, hogy milyen teljesítményt nyújt az új csapatban), valamint nem homogén a piac. A hivatásos labdarúgóklubok a játékospiac mellett saját utánpótlásukból is feltölthetik az általuk múködtetett csapatot, tehát a vásárlásnak egyértelmúen helyettesítője lehet az utánpótlásba történó befektetés. Jelen dolgozatnak nem célja az utánpótlásba történő befektetés megtérülésének vizsgálata, de szükséges megemlíteni, hogy a különböző stratégiával múködő klubok különböző utat választhatnak a játékosok megszerzésére. A „nevelni vagy vásárolni” kérdést többek közt befolyásolja a klub rendelkezésére álló pénzügyi források mértéke, a szurkolók és szponzorok játékosokkal kapcsolatos elvárásai, valamint a sportszakmai célok is. Egy nemzetközi szinten sikereket elérni kívánó sportvállalat az adott poszton legjobbak közé tartozó, de más klub által felnevelt játékost vásárol, hiszen minden téren a legerôsebb csapatok egyikét kívánja felépíteni. A kevésbé tehetősebb klubok pedig, amelyek nem rendelkeznek elég nagy tulajdonosi tőkével és nemzetközi piacmérettel, kénytelenek a legjobb játékosaiktól megválni. Erre mutat példát Akgündüz és Berg (2013), akik szerint a holland klubok kénytelenek túladni kulcsjátékosaikon, mert nem tudják felvenni a fizetési versenyt az angol klubokkal. Dolgozatomban kifejezetten a hivatásos játékosok vásárlásához kapcsolódó befektetések hatását vizsgálom.

Sokáig az Európai Unió a személyek (kiemelten a munkavállalók) szabad mozgásával kapcsolatos szabályába ütközött a labdarúgás átigazolási rendszere, ugyanis a lejárt szerződésú labdarúgóért is kérhetett ellenértéket az eladó klub. Jelentős változásokat hozott azonban az úgynevezett Bosman-szabály, amikor az Európai Bíróság azt mondta ki (European Court 
of Justice, 1995), hogy az EU-n belül a munkaeró szabad áramlását a labdarúgóknál is biztosítani kell, valamint a külföldi játékosok korlátozása szintén nem szabályszerú. A szabály lényege, hogy csak érvényes szerződéssel rendelkező labdarúgóért kérhetett a klubja pénzt (tehát lejárt szerződéssel ingyen távozhat a labdarúgó a klubjától és már csak leendő klubjával kell megegyeznie, a két klubnak nem kell szerződést kötnie), valamint a 23 év alatti játékosok átigazolása után kompenzációs díjat kellett fizetni a nevelóegyesületnek (Szymanski, 2014).

Jelen tanulmánynak nem célja a Bosman-szabály részletes bemutatása és következményeinek tárgyalása, így itt csupán három, témánk szempontjából lényeges következményét emelném ki:

- a Bosman-szabály bevezetése óta több mint megháromszorozódott a lebonyolított transzferügyletek száma, értékük pedig majdnem 7,5-szerese lett a kiinduló adatnak 2011-re (KEA - CDES, 2013, p. 242.),

- a szabályozás végső soron a klubok közötti sportszakmai és pénzügyi különbségeket növelte, mert a humán erôforrás, vagyis a játékosok szabadabb mozgását tette lehetóvé, és így a legnagyobb klubok folyamatosan igazolják a legjobb játékosokat,

- a klubok egy része azonban nem bírta kitermelni a leigazolt sztárok transzferdíját és fizetését, így egyre többen halmoztak fel komoly tartozásokat, vagy mentek csődbe.

Az UEFA évek óta figyelemmel kíséri a nemzetközi kupákban részt vevó klubok pénzügyi teljesítményeit és a gazdasági csődöt jelentő sportvállalatok számának csökkentése, valamint az egészségesebb pénzügyi múködés érdekében 2010-ben bevezette a Financial Fair Play (FFP) elnevezésú szabályozását. E szabályozás szerint a nemzetközi kupákban szerepló labdarúgókluboknak a költéseiket a bevételeikhez kell igazítaniuk, a tulajdonosok tőkepótlását pedig korlátozzák. Három év átlagában nézik az eredményeket, korlátozzák a kölcsön felvételének lehetőségét is. Szankcióként figyelmeztetést, bírságot, pontlevonást, versenysorozatban elért eredmények alapján kapott bevételek visszatartását, játékospiacról történő kizárást, játékosok számának korlátozását, vagy versenyrendszerből történő kizárást is alkalmazhatnak (UEFA, 2010; UEFA, 2012). Az FFP-nek történő megfelelés miatt különösen fontos a kluboknak a játékosokkal kapcsolatos kiadások visszafogása, ami az egyre dráguló erőforrás minél hatékonyabb használatára kényszerítheti őket.
A következőkben bemutatom a játékosokba történó befektetés elméleti hátterét, valamint a nemzetközi szakirodalom alapján rávilágítok a különböző tényezők közötti fö összefüggésekre.

\section{A játékosokba történő befektetés (transzfer és bérköltség) hatása a sportvállalatok sportszakmai és pénzügyi eredményeire}

A játékosokhoz kapcsolódó kiadások megtérülését a klubok játékosokkal kapcsolatos üzleti modellje határozza meg, vagyis hogy milyen keretek között és hogyan éri meg játékosok fejlesztésébe invesztálni. András (2003) a labdarúgó-vállalatok múködésének egyik fontos jellegzetességére hívja fel a figyelmet, miszerint a klubok kettős, néhol egymásnak ellentmondó célrendszerrel múködnek: egyszerre van jelen a sportbeli és a gazdasági múködés eredményességének követelménye. Ezek mértéke különböző lehet, de mind a gazdasági társaságokat szabályozó törvények, mind pedig az UEFA gazdaságos múködésre irányuló előírásai (FFP) elvárják legalább a nullszaldós múködést. Mindemellett a kettôs célrendszer egy másik aspektusban is megjelenik, ugyanis a sportvállalatok esetében is megfigyelhetô a kettôs értékteremtés (Chikán, 2008), azaz egyszerre kell a fogyasztó, illetve az ügyfél és a tulajdonos számára értéket teremteni. „Ugyanaz a folyamat, melynek során a vállalat az ügyfél számára értéket állít elő, egyúttal értéket kell, hogy jelentsen a tulajdonos számára is. Az a vállalat, amelyik nem az ügyfelei igényeire reflektál, hosszú távon nem tud nyereséges lenni, és így hosszú távon fennmaradni" (András, 2003, p. 15.).

A játékospiac múködésének megértéséhez fontos megismernünk a döntéshozók szempontjait. A hivatásos labdarúgóklubok legfontosabb eróforrásai maguk a játékosok.

A klubok költségvetésének legnagyobb részét a rájuk költött összegek teszik ki, ezért stratégiai kérdésnek tekinthető, hogy mekkora költségvetés áll a klub rendelkezésére a játékosállomány kialakításakor. A következókben azt mutatom be, hogy a meglévő empirikus tanulmányok milyen kapcsolatot tudtak azonosítani a játékosok teljesítménye, bérezése, valamint a klubok sportszakmai és pénzügyi eredményeire vonatkozóan. Az 1. táblázat összefoglalóan mutatja be a témában született dolgozatokat, a cikkek feldolgozása során tapasztalt gondolati keretek és hangsúlyos pontok szerint csoportosítva, e logikai keret alapján mutatom be én is az egyes összefüggéseket. 


\section{Nemzetközi kutatások összefoglalása a négy nagy bajnokságban}

\begin{tabular}{|c|c|c|c|}
\hline $\begin{array}{l}\text { Kapcsolatok/ } \\
\text { bajnokság }\end{array}$ & Játékosteljesítmény és fizetés & $\begin{array}{l}\text { Játékosokra forditott ki- } \\
\text { adások és sportsikerek }\end{array}$ & $\begin{array}{c}\text { Sportsikerek és klubok árbevétele, } \\
\text { pénzügyi eredménye }\end{array}$ \\
\hline Németország & $\begin{array}{l}\text { Lehmann - Schulze (2007) } \\
\text { Franck - Nüesch (2010) }\end{array}$ & & Stadtmann (2006) \\
\hline Anglia & $\begin{array}{l}\text { Preston, T. (2011) } \\
\text { Gerrard - Dobson (2000) }\end{array}$ & $\begin{array}{c}\text { Cermichael et al. (2010) } \\
\text { Szymanski - Kuypers } \\
\text { (1999) } \\
\text { Szymanski (2014) } \\
\text { Hall et al. (2002) } \\
\text { Brady et al. (2008) }\end{array}$ & $\begin{array}{l}\text { Cermichael et al. (2010) } \\
\text { Benkraiem et al. (2011) } \\
\text { Drawerl - Fuller (2002) } \\
\text { Fotaki et al. (2009) } \\
\text { Dobson - Goddard (1998) }\end{array}$ \\
\hline Spanyolország & $\begin{array}{l}\text { Garcia-del-Barrio - Pujol } \\
\text { (2007) }\end{array}$ & & \\
\hline Olaszország & Lucifora - Simmons (2003) & & \\
\hline
\end{tabular}

Forrás: saját szerkesztés

Ahhoz, hogy megértsük egy klub vezetése és a tulajdonosa döntéseinek hátterét, meg kell ismernünk a különböző hatásokat és azok mögött meglévő összefüggéseket. A gondolati ív kiinduló pontja szerint a sportvállalatok többet költenek játékosok vásárlására és fizetésére, amely hatással van a játékosok és a csapat teljesítményére sportszakmai és pénzügyi értelemben is. Az összefüggések erősségét és a nemzetközi kutatások következtetéseinek alátámasztását mutatom be a következőkben.

\section{A szupersztár-hatás értelmezése a hivatásos labdarúgásban}

Rosen és Adler tekinthetók a szupersztárokkal, illetve az ő különleges piaci helyzetükkel kapcsolatos kutatások úttörőinek, fogalomhasználatuk mégis kissé eltérō. Rosen (1981) írta le először, hogy bizonyos piacokon (fóleg a szórakoztatóiparban, így a film, a múvészetek és a sport területén) a szereplők tehetsége közötti kis különbség is lényegesen nagyobb különbséget jelenthet a fizetésekben. A nézők a magas minőséget értékelik, a jobb minőségért hajlandók lényegesen többet fizetni. Adler (1985) a szereplők tehetsége mellett azok ismertségét is kulcsfontosságúnak tartotta, véleménye szerint ahhoz, hogy értékelni tudjuk a múvészek, sportolók teljesítményét, meg kell ismernünk óket, az embereknek fel kell építeniük a róluk alkotott képet, tudást és minél többször kell, hogy beszéljenek róluk. Az imázs nagy szerepe miatt ,az arculat tudatos alakítása minden labdarúgó-társaság számára a piaci siker egyik előfeltétele. A labdarúgás arculatának részét képezik a fogyasztók összetételének, a futballvállalat kultúrájának, az alkalmazottak, játékosok megjelenésének, viselkedésének jellemzői” (András, 2003, p. 41.).
A sztárok megismerését segítik a jó kapcsolatok is, valamint ezek a hatások egyre erősítik egymást, ezt nevezi Adler szupersztár-hatásnak. A médiának azért van különleges szerepe a sztárcsinálásban, mert nagy hálózattal rendelkezik és gyorsan tud valakit ismertté tenni. Adler szerint nemcsak a tudásbeli különbség, hanem a média is okozza a szupersztárok kiugró fizetését. Lehmann és Schulze (2007) ezt a szupersztár-hatást vizsgálták a német Bundesligában. A labdarúgók egyéni teljesítményét és a médiában történő megjelenésüket elemezték azzal a céllal, hogy megtudják, a teljesítmény és a népszerúség hogyan hat a fizetésekre és a játékosok ismertségére. Eredményük szerint az 1998/1999-es német bajnokságban a játékosok legjobban kereső öt százaléka több mint ötszörösét kereste, mint a medián. Azt próbálták kideríteni, hogy vajon a teljesítményből fakadó különbségek okozzák-e a fizetésbeli különbségeket (Rosen elméletének megfelelóen), vagy inkább a média által keltett népszerüség van hatással a fizetésbeli különbségekre. Eredményeikkel nem tudták igazolni egyik elméletet sem, de azt igen, hogy a teljesítmény és az ismertség valóban hatással van a fizetésekre, mégpedig arányosan: aki jobban teljesít, többet keres, aki népszerúbb, több szponzort, merchandising-bevételt és nézôt hoz a klubnak, ezért díjazni kell ôt, de nincs szó aránytalanságról. A német labdarúgásban a béreket leginkább meghatározó tényezó a csapat sikeressége volt. Úgy találták, hogy a teljesítményt és a népszerúséget arányosan díjazták a sportvállalatok a különböző játékosok esetében.

A német ligával ellentétben a spanyol és az olasz bajnokságban más szerzők igazolták a szupersztár-hatás jelenlétét, de azokban a bajnokságokban a legjobb klubok lényegesen gazdagabbak a többiekhez képest (főleg a televíziósdíjak egyenlőtlenebb elosztása miatt). 
A szerzők megjegyzik, hogy a másik két liga esetében a kutatók nem ugyanazt a módszertant használták az elemzésükhöz és a fizetési adatok megbízhatósága is kérdéses. Lehmann és Schulze (2007) további eredménye, hogy a játékosok esetében 25,4 éves kornál találtak fordulópontot a fizetések változásában (ez után kezdett csökkenni), valamint az idegenlégiósok közül a dél-amerikai játékosokat az arányosnak mondhatónál jobban megfizették, pedig a magasabb fizetéssel nem járt magasabb szintú teljesítmény is.

A tehetség mellett a népszerúség is jelentősen hozzájárul a sztárok piaci értékéhez, ezt a német bajnokság adataiból kiindulva igazolta Franck és Nüesch (2010). A jobban összehasonlítható sportágak esetében és az egyéni sportokban természetesen jobban összemérhetők a sportolók, a labdarúgásban mindez nehezebben végezhetô el. A csapat teljesítménye mellett az egyéni teljesítményeket is követték, és így próbáltak meg számszerúsíteni a sikerességet. Eredményük szerint az egyéni teljesítmény és a média is szignifikánsan hozzájárul a piaci érték különbözőségének meghatározásához.

Nemcsak a német, hanem az olasz labdarúgás adatait elemezve is igazolták Rosen szupersztár-elméletét (Lucifora - Simmons, 2003), de Olaszországban csak a középpályások és a csatárok esetében kaptak szignifikáns eredményt. A szerzők eredményei szerint a nemzeti válogatottban való szereplés nagyobb fizetést eredményez a játékosok számára. Garcia-del-Barrio és Pujol (2007) a spanyol bajnokságra nézve azt igazolták, hogy a szupersztárok a várható érték felett keresnek az értékelésük, a Google-találatok és a szokásos kontrollváltozók alkalmazása mellett.

\section{Kapcsolat a játékos fizetése és egyéni sportteljesítménye között}

Franck és Nüesch (2010) a tehetségek, szupersztárok szereplésének hatását vizsgálták a csapat teljesítményére vonatkozóan a német első osztály adatait felhasználva. Eredményeik szerint igazolható kapcsolat van a kiemelkedő játékosok teljesítménye és a csapat helyezése között. Franck és Nüesch (2012) másik cikkében a csapaton belüli bérkülönbségek hatását elemezte a csapat teljesítményére vonatkozóan. Véleményük szerint kettôs a megítélése a bérkülönbségeknek, mert egyrészt a magasabb bér elérésének lehetôsége nagyobb munkára ösztönöz (látják, hogy megtérül a befektetett munka), másrészt viszont csapaton belüli ellentétekhez, és így a csapat teljesítményének csökkenéséhez vezethet. A német első osztályú bajnokság adatain végzett elemzésük szerint U-alakú kapcsolat van a bérkülönbségek és az eredmények között, amely szerint a fizetésekben kiemelkedő eltéréseket, valamint a fizetések között minimális különbségeket alkalmazó csapatok érték el a legjobb eredményt, míg a közepesnek mondható fizetésbeli különbségek okozták a leggyengébb csapatteljesítményt. A szerzők szerint sok minden függ a csapaton belüli kultúrától (mennyire jellemző az egyénieskedés, kooperáció, csapatmunka), és az edzó fellépésétől, de ha egyértelmú a csapaton belül a hierarchia (van 1-2 jól megfizetett tehetség, akikre a többiek felnéznek), az sokkal szerencsésebb, mintha több egyénieskedő játékos lenne. A nagy különbség egyrészt magyarázható azzal, hogy néhány kiemelkedő képességú játékost a többiek is elismernek (szakmailag is, valamint a csapat jó szereplése mindenkinek hasznos), másrészt a legjobb teljesítményt nyújtó csapatoknál vannak a legjobb játékosok, akiknek csúcsfizetésük van, az ő fizetésüknél lényegesen kevesebbet (de nem keveset) tudnak fizetni a többieknek.

Azonban egy játékos javadalmazása nemcsak a saját teljesítményétől függ. Ruijg és Ophem (2014) írása szerint a klubok elsősorban azért vásárolják a játékosokat, mert velük erősebb lesz a csapat és javulhat a sportteljesítmény, a játékosokat pedig a csapat teljesítményéhez való hozzájárulásuk alapján is díjazzák prémium formájában. Ez logikus is, mert a sportsikerek hatással vannak a pénzügyi sikerekre, hiszen több jegyet adnak el, valamint a merchandising és szponzori bevételek is nőnek. Ugyanakkor megjegyzik, hogy egy játékos kölcsönvétele, vagy vásárlása kockázatokat rejt magában. A játékos hatékonysága időben változékony, függ a csapat többi részétól, valamint az ellenfelek erejétôl is. Függhet még a pénzügyi siker többek között a gazdasági környezettől, a nemzeti válogatott teljesítményétől, vagy más sportágak népszerúségétól is. A játékos költségei között kell említeni a fizetést és az esetleges átigazolási díjat is (amennyiben még érvényes szerződése volt). Ez utóbbi közgazdaságtanilag kétféle kompenzációt jelent az eladó klub számára: egyrészt elvesztett termelékenység a játékos szerződésének idejére, másrészt pedig a játékos korábbi vásárlása, vagy kinevelése miatti befektetett tóke. Korábbi tanulmányok (Lehmann - Schulze, 2007, vagy Franck - Nüesch, 2010) erôs, pozitív kapcsolatot találtak a fizetések, az átigazolási díjak és a termelékenység (teljesítmény) között, de a fizetésekról nagyon kevés hiteles adat van, valamint az átigazolásokról is korlátozott az adatok elérhetősége.

A különleges képességekkel rendelkező labdarúgók extra teljesítményének elismerése indokolt lehet a klubok által. A mindkét lábukkal kiválóan játszó labdarúgók fizetésének különbözőségét vizsgáló tanulmány (Bryson et al., 2009) szerint a kereslet nagyobb lehet a mindkét lábával kiválóan játszó játékosok iránt, ugyanis a labdarúgók döntő többsége alapvetően jobblábas. A szerzők az öt, nagy, európai bajnokságot, valamint a német ligát külön is vizsgálták, és eredményeik szerint jelentős fizetési prémiumot kapnak a mindkét lábukkal 
jól játszó játékosok (a különbség a játékos posztjától is függ). Miért is lehet a „kétlábas” játékosok fizetésében eltérés? Egyrészt eleve jobb teljesítményre képesek, másrészt az edzőknek extra lehetőséget jelentenek a csapat összeállításánál. Nem tudták alátámasztani a „kétlábas” játékosok szereplésének jelentős hatását a csapat teljesítményére, csak a középpályások esetében tudtak teljesítménykülönbséget kimutatni, fizetésben mégis többet kapnak. A ballábas játékosok esetében is a középpályásoknál van fizetésbeli különbség, de nem akkora, mint a „kétlábasok” esetében. A csak Németországra vonatkozó kutatásban viszont igazodott a fizetéshez a teljesítmény is. Sokkal inkább függhet a dolog attól, hogy olyan csapatot talál-e magának a „kétlábas” játékos, ahol kuriózumnak számít és a játékrendszerben nagyobb hasznát veszik, mint sem pusztán a tény, hogy kétlábas.

Összességében tehát erôs, pozitív kapcsolat mutatható ki a játékosok teljesítménye és fizetésük között, mind a négy nagy liga esetében készült tanulmány ennek alátámasztására (lásd az 1. táblázat első oszlopát). Kiemelkednek azonban a szupersztárok, mert nehezen helyettesíthetô erôforrásnak számítanak, ezért áruk is exponenciálisan nagyobb, mint a társaiké (nem arányos a teljesítménynövekménnyel) (Franck - Nüesch, 2012).

A játékos árára, motiváltságára hatással lehet szerződésének hátralévő ideje, valamint az átigazolásával kapcsolatos médiafigyelem is. Feess et al. (2003) játékelméleti tanulmányban vizsgálták a szerződésekkel kapcsolatos viselkedéseket, többek között azt írják, hogy a szerződés aláírásakor mind a klub, mind pedig a játékos a nagyobb haszon elérését túzi ki célul. Minél rövidebb idő van hátra a szerződésből, a játékos annál inkább érdekelt a jobb teljesítményben, hogy utána új szerződést tudjon aláíni. Másrészről az új klubnak is érdeke lehet a meglévő rövidebb szerződés, mert ingyen juthat a játékoshoz a lejárat végén, vagy olcsóbban, ha kevesebb idő van a szerződésből hátra. Minél több idő van hátra egy játékos szerződéséből, annál kisebb az esélye az átigazolásnak. A német bajnokság 1994-2000 közötti átigazolási szerződéseit vizsgáló tanulmány (Feess et al., 2010) szerint egy évvel hosszabb szerződési idő jelentősen növeli az átlagos transzferértéket. A játékosok fizetése az új csapatban többnyire növekszik a korábbi fizetésükhöz képest. A Bosman-szabály bevezetése után a megkötött szerződések időtartamának növekedését figyelték meg, a korábbi 2,8-2,9 év helyett 3,2-3,3 évre nőtt a szerződések átlagos hosszúsága.

\section{Kapcsolat a játékosokra fordított kiadások és a csapat sportteljesítménye között}

A labdarúgás csapatsport, így az egyéni képességek mellett számos egyéb tényező befolyásolja a csapat által nyújtott sportteljesítményt (társak teljesítménye, szakmai stáb felkészültsége, infrastrukturális lehetóségek, versenytársak erôssége stb.), ezért fontos a játékosokra költött pénzösszegek hatását a csapat teljesítményére vonatkozóan is megvizsgálni. Az angol labdarúgásban erős pozitív kapcsolatot igazoltak a sportsikerek és a bérjellegú kiadások (Szymanski - Kuypers, 1999), valamint a ligahelyezés és a bérjellegú kiadások között (Hall et al., 2002). A szerzők értelmezése szerint a klubok jó információkkal rendelkeznek a játékosaik képességéről, és azért fizetnek nekik, hogy ellensúlyozzák a klub sportcéljainak elérése érdekében tett erőfeszítésüket, termelékenységüket. A klubok igyekeznek ezt a pénzügyi ellentételezést elfogadható pontossággal kielégíteni, hogy a játékosok annyit kapjanak, amennyit érdemelnek. Eredményeik konzisztensek a siker (sikertelenség) körkörösségével, vagyis a sikeresebb kluboknak lesz képességük a humán tốkébe fektetni még többet. Nagyon fontos megállapítás, hogy egy meredek emelkedés a bérköltségekben csak kisebb mértékú növekedést okoz a megszerzett ligapontokat tekintve, tehát erőn felül kell áldozni a játékosokra a jobb eredmények érdekében. Ennek oka, hogy a klubspecifikus hatások és a nemzetközi kupák sikeressége is befolyásolja a bevételeket, amelyek nem függnek a ligától. Ugyancsak jelentős pozitív korrelációt mutattak ki az átlagos bérköltések és a sportsikerek között az angol első két osztályban (Szymanski, 2014).

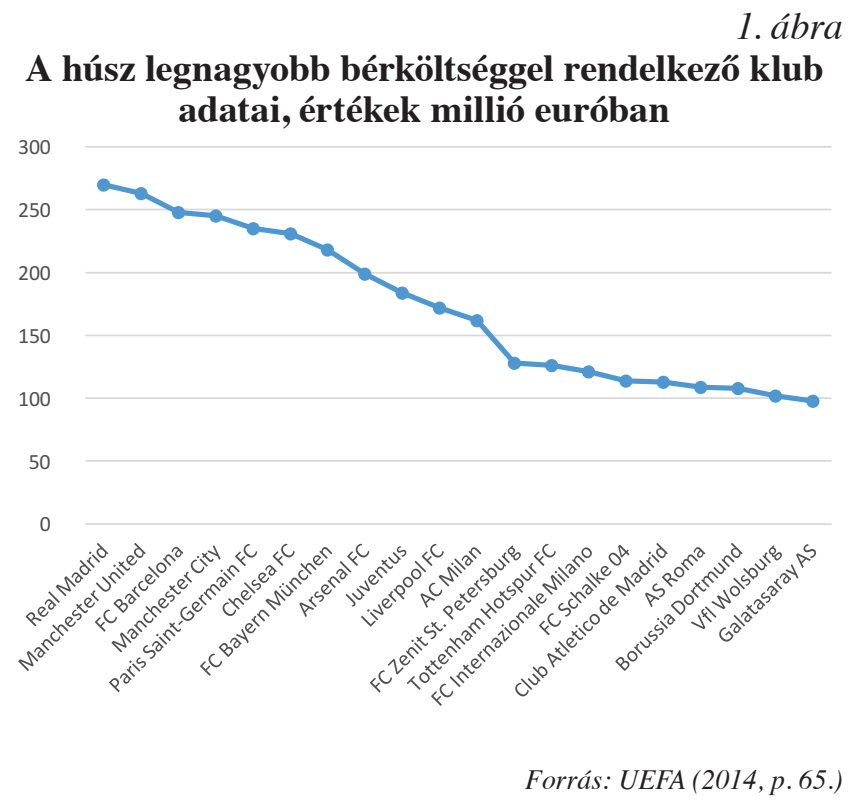

Az UEFA az európai klubok 2014-es pénzügyi évét vizsgáló tanulmányában (UEFA, 2014) a húsz legnagyobb bérköltséggel rendelkező klub eredményeinek vizsgálatakor azt találta, hogy átlagosan a teljes bevételük 57\%-át költötték bérjellegú kiadásokra, amelyek 
az előző évhez képest átlagosan 9 százalékkal nőttek. Az átlagos bérköltésük 172 millió euró volt, a húsz klub bérjellegú kifizetése összesen pedig 3.446 millió euró. $\mathrm{Az}$ 1. ábrán látható a húsz klub bérköltéseinek megoszlása, amely mutatja, hogy igen nagy eltérés van a legtöbbet költố klubok között, például az elsô, spanyol Real Madrid 2,75-ször annyit költ bérekre, mint a huszadik, török Galatasaray.

A játékosok egyéni képességeinek összegzése azonban nem közvetlenül mutatja a csapat teljesítményét, mert más tényezők is segítik a jobb csapateredmény elérését, többek közt az edző személye, tudása (Brady et al., 2008). Emellett fontos, hogy nem elég a tehetségek, szupersztárok megvásárlása, hanem kiemelten fontos a folyamatos fejlesztésük is, ami egyrészt jelenti a sportszakmai fejlesztésüket, másrészt pedig a brandjük építését.

Brady és szerzôtársai (2008) szerint a bevételek pozitív kapcsolatban állnak (a korábbi és jelenlegi) sportsikerekkel, és a sportvállalatok bevételeik több mint a 60 százalékát a játékosok bérére költik. Mivel a bérköltségek a játékosok sportképességein alapulnak, a játékosokba történő befektetés sikereket eredményez a pályán (kutatásukban az angol bajnokságban és a nemzetközi kupákban). A sikeres klubok még gazdagabbak lesznek és képesek lesznek tovább építeni sikerességüket azáltal, hogy többet költenek játékosokra, mint a kevésbé tehetős klubok. A nagy klubok abban érdekeltek, hogy a különbség köztük és a kisebbek között minél nagyobb legyen, így fenntartva az egyensúlytalanságot. Ez nemzeti dominanciához vezet minden bajnokságban. Szabályozással lehetne ezen változtatni, például fizetési plafon bevezetésével, a csapat játékosszámának maximalizálásával, a játékosok mobilitásának csökkentésével, de ezeket a lehetséges szabályozásokat az összes nagy bajnokság elutasította, és egyelőre „átoknak” tekintik a vezető klubok.

\section{Sportsikerek és a klubok árbevétele, pénzügyi eredménye}

Az Európai Labdarúg Szövetség (UEFA) 2008 óta évente készíti el a kontinens klubfutballjának gazdasági adatait tartalmazó jelentését, amelyben fóként a nemzetközi versenykiírásokban szereplő klubok gazdálkodását vizsgálják meg. Már a 2008-as UEFA-jelentésben (UEFA, 2008, p. 49.) is a sportsiker és az árbevétel közötti pozitív kapcsolatot mutattak ki, majd a 2009-es jelentésben (UEFA, 2009, p. 74.) két fontos trendet emeltek ki: egyrészt óriási különbségek vannak a legjobb bajnokságok klubjainak sporteredményei és pénzügyi eredményei között is, másrészt a személyi jellegú kiadások és a sportsikerek között exponenciális a kapcsolat: egységnyivel jobb sportsikerhez lényegesen nagyobb ráfordításra van szükség a játékosok átigazolásában és fizetésében.

Cermichael és szerzőtársai (2010) a sportteljesítmény és pénzügyi sikerek kapcsolatát vizsgálták az angol elsố osztály adatai segítségével. Eredményeik szerint a klubok sportteljesítménye közvetlenül következik a játékosok képességeiből, valamint a bevételek is pozitív kapcsolatot mutatnak a sportteljesítménnyel. A bérköltségek szintje erős kapcsolatot mutat a játékosok képességeivel és teljesítményével. Egyértelmú következtetésük, hogy a játékosállomány minőségének fejlesztése sportsikereket eredményez, valamint a gazdagabb klubok még gazdagabbak lesznek és képesek a sikereiket is tovább építeni azáltal, hogy több pénzt költenek játékosokra, mint a kevésbé sikeres klubok. Mindaddig, amíg a gazdagabb klubok elérik a kitúzött céljaikat és megkapják a különböző piacokon elérhető bevételek nagy hányadát, okozati összefüggés marad a realizált árbevétel és a játékosok befektetésen alapuló versenyképességi egyensúlytalansága között. A játékosok értékének meghatározása igen nehéz, mert hirtelen értékvesztés is bekövetkezhet, például sérülés esetén, de más fizikai és pszichológiai okok is komoly teljesítményváltozást eredményezhetnek. A játékosok jövőbeni teljesítményét nehéz elóre jelezni, és így az immateriális javak elkövetkező jövedelemtermelési képességét is nehéz meghatározni. Azonban a mérkőzést befolyásoló játékvezetői ítéletekről sem feledkezhetünk meg. A klubok kereskedelmi és pénzügyi kockázattal számolhatnak, amelyek ahhoz kapcsolódnak, hogy az árbevétel nagyban függ a sportteljesítménytől. Közvetlenül befolyásolja a sportteljesítmény a kilátogató nézők számát, a fogyasztói piac bevételeit, közvetetten pedig a többi piacról származó bevételt, a szponzori, a TV és a merchandising termékekből eredő összegeket.

A labdarúgó-vállalatok egy része részvénytársasági formában múködik, akik esetében a pénzügyi teljesítményt transzparensen szükséges bemutatni. Benkraiem és szerzőtársai (2011) a tőzsdén szereplő angol klubok sportteljesítményét és a részvényárak ingadozásainak kapcsolatát elemezték. Véleményük szerint egyre jelentôsebb a labdarúgásban az immateriális javak mértéke és igen nehéz ezeket értékelni (valós értékét meghatározni). Következtetéseik szerint a sporteredmények jelentôs hatással vannak a részvényértékekre, a tôzsdei reakciók nagysága nagyban függ az eredménytől (győzelem, döntetlen, vereség) és a mérkőzés helyszínétől (otthon, idegenben). Megállapításuk szerint a hazai pályán elszenvedett vereségnek van a legnagyobb negatív hatása. Tizenhét brit klub eredményeit vizsgálták a tőzsdén 1995 és 1998 között, és azt találták, hogy a mérkőzést követô napon a győztes mérkőzés egy százalékos növekedést, a döntetlen 0,6 százalékos csökkenést, a vereség pedig 1,4 százalékos csökkentést eredményezett. 
Hasonló eredményt talált Allouche és Soulez (2005), valamint Renneboog és Vanbrabant (2000) is: az árfolyamra gyakorolt hatás pozitív győzelem, nemzetközi kvalifikáció és kupasiker esetén, de negatív vereség és valamely versenykiírásból történő kiesés során. Stadtmann (2006) is ezt mutatta ki a német Borussia Dortmund $\mathrm{GmbH} \&$ Co. példáján. Fotaki és szerzőtársai (2010) a vállalati pénzügyeket és az eróforrás-alapú elméletet együtt elemezték a vállalati eszközök beszerzése, értékesítése és fejlesztése terén. Tizenöt, tőzsdén szereplő angol klub elemzése segítségével vizsgálták a játékosok vásárlásának, eladásának és kölcsönzésének a részvényesek vagyonára gyakorolt hatását. Rámutattak, hogy a játékoseladás és -kölcsönadás abnormális részvénymozgásokkal párosult az esemény idópontja körül, véleményük szerint a befektetôk a játékospiacot nem ítélik hatékonynak. A szerzők a tartós versenyelőny zálogának tekintik a sportvállalat immateriális javakkal történő helyes gazdálkodásának képességét. A vállalatoknak (a sportvállalatoknak pedig még inkább) meghatározott időként értékelniük kell a humán erőforrásukat, illetve annak teljesítményét, hatását a szervezetre. További kutatási lehetőséget rejt annak elemzése, hogy miért cseréli ki időnként egy sportvállalat a humán eróforrását, és van-e ennek hozzáadott értéke a vállalatra vonatkozóan.

2. ábra

A hét legerósebb bajnokságban a klubok átlagos bérköltségeinek különbsége az 1-4., 5-8. és 9-20. helyezést eléró klubokban, adatok millió euróban

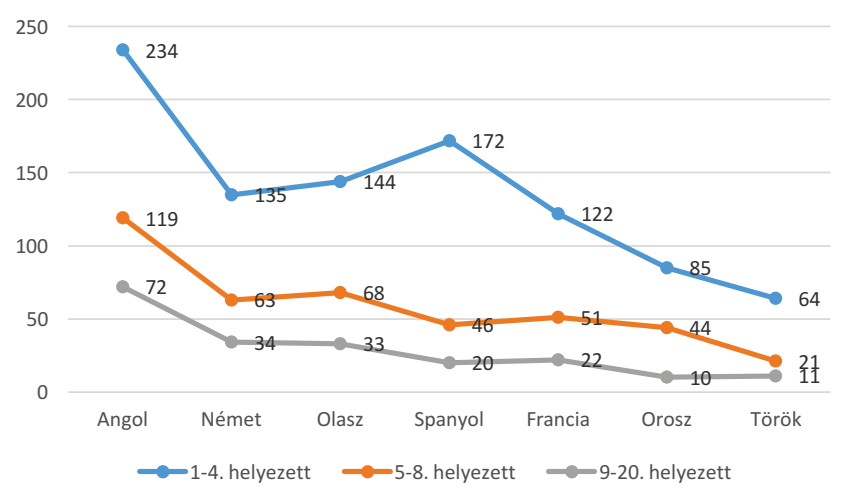

Forrás: UEFA (2014, p. 67.)

Az UEFA legfrissebb éves pénzügyi jelentése (UEFA, 2015, p. 67.) szerint erős összefüggés van a bajnokságban elért helyezés és a bérköltségek között. A 2. ábrán látható, hogy minden vizsgált bajnokságban nagy az eltérô sporteredményeket elérô klubok átlagos bérköltsége közötti különbség, főleg a bajnokság első négy helyezettje és a többiek között, ami azért is kiemelten fontos, mert fóként ők tudnak nemzetközi versenykiírásokban indulni, és ennek köszönhetően nemzetközi piacokon tovább tudják növelni fogyasztóik számát és árbevételüket. Ennek köszönhetóen pedig újra ők fektethetik a legtöbb pénzt új játékosok igazolásába, illetve magasabb fizetésekbe.

Drawerl és Fuller (2002) a sérülések kockázatelemzésén keresztül kiválóan kapcsolta össze a fenti összefüggéseket és foglalta össze a kapcsolatok lényegét. Véleményük szerint a vezetés (és a humánerőforrás-menedzsment) célja, hogy becsülje, értékelje és kontrollálja a felmerülő kockázatokat, a legfontosabb erőforrás, a játékosok kapcsán is. A hivatásos labdarúgásban a sérülés lényegesen nagyobb veszélyt jelent, mint más területeken. A legnagyobb probléma, ha egy hivatásos klub játékosai nem állnak rendelkezésre és így nem tudnak a sportbéli és pénzügyi teljesítményhez hozzájárulni. A cikk egy statisztikaalapú kockázatelemzési modellt mutat be, amely a csapat minőségét, a csapat teljesítményét, a klub bevételét és a klub bérköltségeit vizsgálja az angol bajnokság 1993-1997 közötti időszakában. A modell pozitív korrelációt talált az említett négy tényező között, valamint egyértelmú kapcsolatot talált a sérülések és a klubok sportbéli, valamint pénzügyi teljesítménye között is. A modell lényege a következő: ha sikerül a csapat értékét, minőségét egy akcióval növelni (sikeres utánpótlás-nevelés, vagy játékosvásárlás), akkor ez meglátszik a csapat sportteljesítményén is. Sok esetben (Dobson Goddard, 1998) azonban az elsô években a bevételek növekedésén még nem tükröződik az elvárt szakmai siker, viszont a bérköltségek folyamatosan növekednek, amit újabb befektetéseknek kell követniük, ha meg szeretnék tartani a csapat minőségét. Sok klub itt hibázik, mert nincs tőkéje évről évre fejleszteni, a bevételeit pedig nem tudja ilyen gyorsan növelni. Példa erre, ha a helyi közönség (a mérkőzésnapi bevétel jelentős) nem tud többet költeni, mert nincs több hely a stadionban, vagy nem elég fizetôképesek a fogyasztók. Az újabb költések elmaradása pedig a megfelelő helyettesítő játékosok igazolását akadályozza meg. Ha sérülés következik be, akkor a csapat minősége eshet vissza, ami a csapat sportteljesítményét csökkenti, ez pedig bevételcsökkenéshez vezethet (sportsikerek után járó pénzek és nézők elmaradása stb.). A gazdagabb klubok nagyobb és minôségi kerettel rendelkeznek, ezért tudják könnyebben helyettesíteni a sérült játékosokat. Azonban a kisebb kluboknak, ha kiesik néhány kulcsjátékosuk, nagyon visszaeshet a teljesítményük (ez is egy nagy szakadék a klubok között). Összességében tehát a sérülések kockázatára is oda kell figyelni a keret méretének és minőségének meghatározásakor. 
A játékosokkal kapcsolatos kiadások, egyéni teljesítmények, csapatteljesítmények, valamint az üzleti megtérülés közötti összefüggések bemutatása

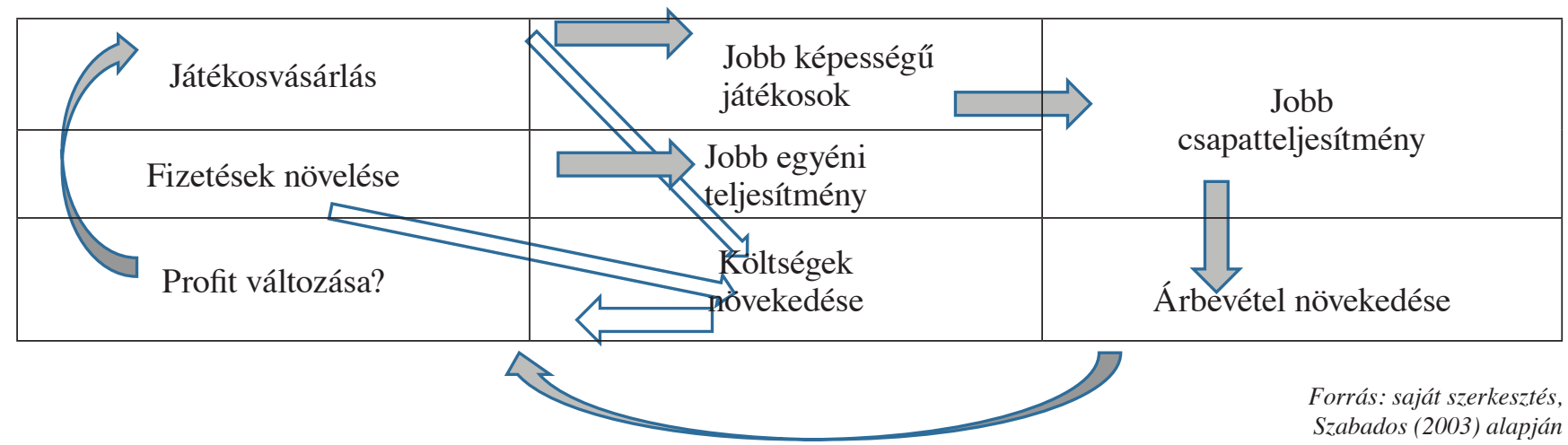

A 3. ábra alapja a Szabados (2003) által bemutatott siker-körstratégia, amely szerint egy előzetes befektetés a sportszakmai munkába, jobb sporteredményeket és a nagyobb bevételt eredményez. Azonban a legtöbb versenysorozatban több klub is ugyanezt a célt túzi ki, így mindig lesznek olyanok, akik nem tudják megnyerni a versenykiírást, és így nem tudják realizálni a nyereséges múködéshez szükséges árbevételt sem, ezt hívjuk Szymanski-csapdának (Szymanski, 1999). A 3. ábra segít a tanulmány fó gondolatainak összefoglalásában. A klubok a jobb csapatteljesítményt alapvetően új játékosok igazolásával, illetve nagyobb fizetésekkel érhetik el, valamint a jobb sporteredmények jelentik az árbevétel növelésének alapját. A kérdés az, hogy tudják-e olyan szinten bővíteni árbevételüket, mint ahogyan a játékosokhoz köthető kiadásaik nőnek. A bevételek növelésében a legnagyobb szerepe a nemzetközi piacokon elért bevételek növelése lehet (újabb fogyasztók, globális szponzorok, további televíziós közvetítések), tehát a hazai bajnokság élmezőnyében kell végeznie, hogy nemzetközi versenysorozatban is szerepelhessen a klub. Fontos, hogy hosszú távú megtérülésben, jövedelmezőségben gondolkozzanak a klubokat múködtető gazdasági társaságok, és néhány év sikertelensége ne lehetetlenítse el a kitűzött stratégiai cél megvalósítását.

Hosszú évek után a 2012-es pénzügyi évben fordult elő az európai hivatásos labdarúgásban, hogy a nemzetközi versenykiírásokban részt vevő klubok összes árbevételének növekedési üteme meghaladta a klubok összesített bérköltségének növekedési ütemét, valamint csökkent a klubok pénzügyi veszteségének mértéke (UEFA, 2013, p. 8.). Hangsúlyozandó, hogy csak a mértéke csökkent a veszteségtermelésnek, összességében még így is jelentős a veszteségek összege, ráadásul évról évre újabb veszteség képződik az iparágban, ami kumulálódik is. Az elmúlt évtizedben az UEFA-versenysorozatokból származó klubbevételek átlagosan évente
12 százalékkal növekedtek (UEFA, 2013, p. 20.). 2012ben, az UEFA-kupákban részt vevő klubok 12 százaléka többet költött személyi jellegú ráfordításokra, mint amennyi a teljes bevétele volt, további tíz százalékuk pedig a bevételeiknek legalább 80-100 százalékát költötték erre. Összesen a klubok 35 százaléka több mint 70 százalékát költötte csak személyi jellegú ráfordításokra a bevételeinek, a felénél kevesebbet mindössze 26 százalékuk (UEFA, 2013, p. 46.).

\section{Összegzés}

Tanulmányomban arra kerestem a választ, hogy miképpen értelmezhető az üzleti értelemben vett humán tớkébe történő befektetés a hivatásos sport esetében, és a nemzetközi empirikus tanulmányok milyen összefüggést találtak a befektetések és megtérülések között. A nemzetközi szakirodalom alapján elmondható, hogy a hivatásos labdarúgásban kimutatható az összefüggés a játékosokra költött pénzösszeg (játékosvásárlás és fizetés), valamint a sportteljesítmény (egyéni és csapatszintû) között, azonban a csapatokat múködtetô sportvállalkozások üzleti eredményessége már nem következik a jó sportteljesítményből. A sikeresebb szereplés hatására ugyan minden piacon nagyobb árbevételt realizálhatnak a klubok, azonban ez a legtöbb esetben a személyi jellegú kiadások (játékosvásárlások és fizetések) olyan jelentős növekedésével jár, hogy az üzleti eredmény gyakran veszteséget mutat. A befektetés megtérülésének fó kérdése, hogy sikerül-e a bevételeket nagyobb mértékben növelni, mint ahogy az ehhez szükséges humán tőkére költött kiadások növekednek. A nagyobb ütemú árbevétel-növekedésnek alapja lehet a nemzetközi piacon elért üzleti eredmények növekedése, vagy a tulajdonosok nagyobb szerepvállalása a klub múködtetésében. Ez utóbbi esetében kérdés, hogy a tulajdonosok egyéb üzleti és más területen nyert szinergiahatá- 
sokkal együtt tudják-e hosszú távon biztosítani az extra forrásokat, illetve meg tudnak-e felelni a nemzetközi szövetség egyre szigorodó szabályázásának. A kutatás kibővítésének egyik lehetôsége az utánpótlás-nevelésre specializálódott sportvállalatok múködésének vizsgálata lehet, hiszen egy eltéró stratégia, eltérő bevételi struktúrát is jelent.

\section{Felhasznált irodalom}

Akgündüz, Y.E. - Berg, van der M. (2013): Make or buy? Human capital accumulation strategies in European club football. Tjalling C. Koopmans Research Institute, Discussion Paper 13-17. Letöltés helye: http://dspace.library.uu.nl/bitstream/handle/1874/290036/13-17. pdf; letöltés ideje: 2016. április 17.

Adler, M. (1985): Stardom and talent. The American Economic Review: p. 208-212.

Allouche, J. - Solez, S. (2005): The stock exchange quotation of English football clubs: a differentiated analysis of the share prices' fluctuations. Unpublished manuscript. University of Paris I.

András, K. (2004): A hivatásos labdarúgás piacai. Vezetéstudomány, Különszám: p. 40-57.

András, K. (2003): Üzleti elemek a sportban, a labdarúgás példáján. Doktori disszertáció. Budapest: BKÁE, Gazdálkodástani PhD-program

András K. - Havran Zs. (2015): New Business Strategies of Football Clubs. Apstract, Vol. 9. Numbers 1-2. Debreceni Egyetem

Benkraiem, R. - Le Roy, F. - Louchichi, W. (2010): Sporting performances and the volatility of listed English football clubs. in: European Financial Management Association 2010 meeting in Aarhus

Brady, C. - Bolchover, D. - Sturgess, B. (2008): Managing in the Talent Economy. California Management Review, 50(4)

Bryson, A. - Frick, B. - Simmons, R. (2009): The returns to scarce talent: Footedness and player remuneration in European football. CEP Discussion Paper No 948, September 2009, Centre for Economic Performance, ISBN 978-0-85328-416-1; letöltés helye: http://eprints.lse.ac.uk/27784/1/dp0948.pdf; letöltés ideje: 2015. október 11.

Carmichael, F. - McHale, I. - Thomas, D. (2011): Maintaining market position: team performance, revenue and wage expenditure in the English premier league. Bulletin of Economic Research, 63(4): p. 464-497.

Carmichael, F. (2006): The player transfer system in soccer. in: Andreff, W. - Szymanski, S. (2006): Handbook on the economics of sport. Great Britain. Bodmin, Cornwall: MPG Books Ltd.: p. 668-676.

Chikán, A. (2008): Vállalatgazdaságtan. Budapest: Aula Kiadó
Dietl, H. - Franck, E. - Lang, M. - Rathke, A. (2011): Organizational differences between US major leagues and European leagues: implications for salary caps (No. 1105).

Dobson, S. M. - Goddard, J. A. (1998): Performance and revenue in professional league football: evidence from Granger causality tests. Applied Economics, 30(12): p. 1641-1651.

Drawer, S. - Fuller, C. W. (2002): An economic framework for assessing the impact of injuries in professional football. Safety Science, 40(6): p. 537-556.

European Court of Justice (1995): 1995.12.15-i ítélet a hivatásos játékosok szabad munkavállalásáról. Letölthetó: http://eur-lex.europa.eu/legal-content/EN/ TXT/?uri=CELEX:61993CJ0415; letöltés ideje: 2015. június 12 .

Feess, E. - Muehlheusser, G. (2003): Transfer fee regulations in European football. European Economic Review, 47(4): p. 645-668.

Feess, E. - Gerfin, M., - Muehlheusser, G. (2010): The Incentive Effects of Long Term Contracts on Performance - Evidence from a Natural Experiment in European Football. Mimeo

Fotaki, M. - Markellos, R. N. - Mania, M. (2010): Human resources turnover as an asset acquisition, accumulation and divesture process. MSL Working Paper Series, 02/10, MSL, AUEB

Franck, E. - Nüesch, S. (2010): The effect of talent disparity on team productivity in soccer. Journal of Economic Psychology, 31(2): p. 218-229.

Franck, E. (2010): Private firm, public corporation or member's association governance structures in European football. International Journal of Sport Finance, 5(2): p. 108-128.

Franck, E. - Nüesch, S. (2012): Talent and/or Popularity: What does it take to be a Superstar? Economic Inquiry, 50(1): p. 202-216.

Garcia-del-Barrio, P. - Pujol, F. (2007): Hidden monopsony rents in winner-take-all markets-sport and economic contribution of Spanish soccer players. Managerial and Decision Economics, 28(1): p. 57-70.

Gerrard, B., - Dobson, S. (2000): Testing for monopoly rents in the market for playing talent - Evidence from English professional football. Journal of Economic Studies, 27(3): p. 142-164.

Hall, S. - Szymanski, S. - Zimbalist, A. S. (2002): Testing causality between team performance and payroll the cases of major league baseball and english soccer. Journal of Sports Economics, 3(2): p. 149-168.

$K E A-C D E S$ (2013): Study on the economic and legal aspects of transfers of players; letöltése helye: ec.europa.eu/sport/library/documents/cons-study-transfersfinal-rpt.pdf, letöltés ideje: 2015. augusztus 11. 
Lehmann, E. E. - Schulze, G. G. (2007): What does it take to be a star? The role of performance and the media for German soccer players (No. 1). Discussion paper series//University of Freiburg, Department of International Economic Policy

Lucifora, C . - Simmons, R. (2003): Superstar effects in sport evidence from Italian soccer. Journal of Sports Economics, 4(1): p. 35-55.

Preston, T. (2011): The Determinants of Football Transfer Market Values. An Age of Financial Restraint. University of Warwick

Renneboog, L. - Vanbrabant, P. (2000): Share price reactions to sporty performances of soccer clubs listed on the London Stock Exchange and the AIM. Tilburg: Tilburg University

Rosen, S. (1981): The Economics of Superstars, American Economic Review, 71: p. 845-858.

van Ophem, H. - Ruijg, J. (2014): Determinants of football transfers (No. 14-01). Amsterdam: Universiteit van Amsterdam, Dept. of Econometrics

Stadtmann, G. (2006): Frequent news and pure signals: the case of a publicly traded football club. Scottish Journal of Political Economy, 53(4): p. 485-504.

Stocker, M. (2013): Tudásintenzív vállalatok értékteremtése. Doktori disszertáció. Budapest: Budapesti Corvinus Egyetem. Gazdálkodástani PhD-program

Szabados, G. (2003): Labdarúgóklubok stratégiái. Vezetéstudomány, XXXIV. évf. 2003. 09.: p. 32-43.

Szymanski, S. (2014): On the ball - European soccer's success can be credited, in part, to the liberalization of the players' market. But what will the future bring? Finance \& Development, March: p. 26-28.

Szymanski, S. - Kuypers, T. (1999): Winners and Lo- sers: The Business Strategy of Football. London: Viking

UEFA (2008): Club Licensing Benchmarking Report Financial Year 2008. Letöltés helye: http://www. uefa.org/MultimediaFiles/Download/Publications/ uefaorg/Publications/01/45/30/45/1453045_DOWNLOAD.pdf Letöltés ideje: 2015. június 15.

UEFA (2009): Club Licensing Benchmarking Report Financial Year 2009. Letöltés helye: http://www. uefa.org/MultimediaFiles/Download/Tech/uefaorg/ General/01/58/53/46/1585346_DOWNLOAD.pdf Letöltés ideje: 2015 . június 15.

UEFA (2010): UEFA Club Licensing and Financial Fair Play Regulations; Edition 2010. Letöltés helye: http:// www.uefa.com/MultimediaFiles/Download/Tech/ uefaorg/General/01/50/09/12/1500912_DOWNLOAD.pdf Letöltés ideje: 2015. július 11.

UEFA (2012): UEFA Club Licensing and Financial Fair Play Regulations; Edition 2012. Letöltés helye: http:// www.uefa.com/MultimediaFiles/Download/Tech/ uefaorg/General/01/80/54/10/1805410_DOWNLOAD.pdf. Letöltés ideje: 2015. július 11.

UEFA (2013): Bechmarking Report on the clubs qualified and licensed to compete in the UEFA competition season 2013/14. Letöltés helye: http://www. uefa.org/MultimediaFiles/Download/Tech/uefaorg/ General/01/99/91/07/1999107_DOWNLOAD.pdf Letöltés ideje: 2015 . június 15.

UEFA (2014): Club Licensing Benchmarking Report Financial Year 2014. Letöltés helye: http://www. uefa.org/MultimediaFiles/Download/Tech/uefaorg/ General/02/29/65/84/2296584_DOWNLOAD.pdf; Letöltés ideje: 2015. november 15. 